ミノ基の窒素原子とビニル基の炭素原子に電子密度が集中し, 式 （3）のよ5な Wurster 型イオンを形成しやすい。この Wurster 型イオン式（3）をへて，フェニル基に対して $\alpha$ 位の炭素原子に カルボニウム・イオンが生成し，p-アミノスチレンの重合反応が 進行するものと考えられる。式（3）のWurster 型イオンでも 窒素原子の不対電子は上にのべた理由からフェニル核の $\pi$ 電子軌 道と共役する。<smiles>[CH2]C=C1CCC2CCC1CC2=O</smiles>

かかる電荷移動重合では, 単量体のイオン化電圧が低いことは 必要条件であるけれども，十分条件ではない。たとえば，ビニル
アントラセン，ビニルナフタリンは十分に低いイオン化電圧を有 するけれども，電子受容体によって重合反応をひき执こさない。 第四アンモニウム・イオン, オキソニウム・イオンとなりらる姪 素原子，酸素原子の $2 \mathrm{p} \pi$ 軌道がこれらの基と接する芳香族核の $\pi$ 電子軌道と共役することがもう一つの必要条件といえよう。

p-アミノスチレンが $N$-ビニルカルバヅールと $p$-クロルア ルを触媒として，効率よく共重合すること， $p$-アミノスチレンが トルェン，ジクロルメタン中よりもアセトニトリル中でより速や かに $p$ クロルアニルによって重合することも，上にのべた機蕞 で $p$-アミノスチレンの重合反応が進行していることを示唆する ものである。

\title{
四塩化炭素の存在下液体㐁硫酸とピリジンの電荷移動型錯合体 によって開始されたメタクリル酸メチルの重合*1
}

(昭昭 42 年 8 月 2 日受理)

$$
\text { 松田実・平山 健 }{ }^{* 2}
$$

四塩化炭素が存在すると液体亜硫酸とピリシンの電荷移動型錯合体はメタクリル酸メチルのラジカル重合を開始することが見い

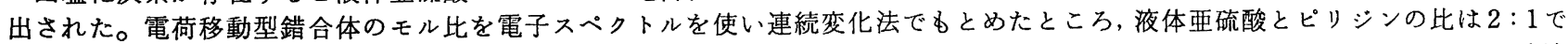
あった。全重合反応速度は錯合体濃度の平方根に，またもノマ一濃度の 1.5 乘に比例した。四塩化炭素濃度の低いところでは全速 度は四塩化炭素濃度の増加とともに急激に增加するが, 四塩化炭素濃度が大きいところでは, 全速度は四塩化炭素濃度に無関係に なる。種々の重合条件下でえられた $k_{\mathrm{p}} / k_{\mathrm{t}}{ }^{1 / 2}$ の值は文献值に一致した。全反応の活性化ェネルギー $(E)$ は $8.2 \mathrm{kcal} / \mathrm{mol} て ゙ あ り$, 開始反応の活性化エネルギーは $k_{\mathrm{p}} / k_{\mathrm{t}}{ }^{1 / 2}$ の值と $E$ より $9.7 \mathrm{kcal} / \mathrm{mol}$ と与えられた。動力学的な考察から重合の開始の機構は液体 亜硫酸とピリジンの電荷移動型錯合体とモノマーとからなる会合錯合体が四塩化炭素を還元し，モノマーラジカルができると推論 した。

\section{1 緒言}

夜体亜硫酸が電子受容体として働き，アミン，エーテル，芳香 族炭化水素，それにある種のオンフィンのような電子供与体と電 荷移動型錯合体をつくることはよく知られている 酸は, ピリジンおよびその誘導体とも電荷移動型錯合体をつくる が4 7)，ピリジンと液体亜硫酸の錯合体が有機ハロゲン化合物の 存在下でビニル系モノマーのラジカル重合を開始させることにつ いてはその概要をすでに報告8)した。四塩化炭素, クロロホルム,

*1この報文を「電荷移動型錯合体によって開始された重合反 応（第1報）」とする.

*2 Minoru MATSUDA, Takeshi HIRAYAMA 東北大学非水 溶液化学研究所: 仙台市片平丁.

1) D. Booth, F.S. Dainton, K. J. Ivin, Trans. Faraday Soc., 55, 1293 (1959).

2) L. J. Andrews, R. M. Keefer, J. Am. Chem. Soc., 73, 4169 (1951).

3) P. A. D. Maine, J. Chem. Phys., 26, 1036, 1042, 1049 (1957).

4) A. Tramer, Bull. Acad. Polon. Sci., Cl. III. 5, 501, 509 (1957).

5) K. R. Hoffman, C.A. Vanderwerf, J. Am. Chem. Soc., 68, 997 (1946).

6) T.Hata, S. Kimumaki, Nature, 203, 1378 (1964).

7）松田, 大井, 未発表.
ブロモホルムなどの有機ハロゲン化合物が重合の開始に関与する ことは $N$-ビニルカルバゾールの重合でも見い出されている ${ }^{9 \sim 11) 。 ~}$ 若干のビニル系モノマーも液体亜硫酸と電荷移動型錯合体をつ くるが ${ }^{12,13)}$, これらの錯合体を含む系のラジカル開始剤存在下の 重合はポリスルホンをつくる ${ }^{12 \sim 14)}$ 。一方，アクリロニトリル ${ }^{15) や ~}$ メタクリル酸メチル16)のラジカル重合はポリスルホンを与えずに 各々のホモポリマーを与えるが，これらのモノマーは液体亜硫酸 と相互作用をもたないことが見い出されている ${ }^{16)} 。$

四塩化炭素の存在下で液体互硫酸と, ピリジンの電荷移動型錯 合体によって開始されたメタクリル酸メチルの重合の結果につい てここで報告する。

8）松田, 石下, 平山, J. Polymer Sci., B 4, 815 (1966).

9) L.P.Ellinger, Polymer, 5, 559 (1964).

10) J.W.Breitenbach, O.F.Olaj, J. Polymer Sci., B, 2 , 685 (1964).

11) H. Nomori, M. Hatano, S.Kambara, ibid., B, 4, 261 (1966).

12) W. G. Barb, Proc. Roy. Soc., A 212, 66, 177 (1952); J. Polymer Sci., 10, 49 (1953).

13）戸倉，松田，工化，64，501（1961）.

14）戸倉，松田，小川，J. Polymer Sci., A 1, 2965 (1963).

15）戸倉，松田，矢崎，Makromol. Chem., 42, 108 (1960).

16）松田, 飯野, 戸倉, ibid., 65, 232 (1963). 


\section{2 実験}

メタクリル酸メチル（MMA）は 10\% のカセイソーダ 水溶液 で 3 回洗い, つづいて水洗を 3 回行なった。無水硫酸ナトリウム 上で乾燥させた後，窒素気流中で減圧下 $(40 \mathrm{mmHg})$ で蒸留し to

四塩化炭素は $5 \%$ の炭酸ナトリウム水溶液，水で洗い，無水硫 酸マグネシウム上で乾燥させ，常王蒸留し bp $78^{\circ} \mathrm{C}$ の留分を用 いた。このものは硝酸銀水溶液と振とうしたが白沈は見られず, フリーの塩素は含まれていない。

トルエンは硫酸, カセイソーダ水溶液, 水銀の順で処理し五酸 化リンで脱水し窒素気流中で分留した。

ピリジンはカセイカリ存在下に窒素気流中で使用直前に毎回減 殴蒸留した。

液体亜硫酸の精製は既報 ${ }^{13)}$ の方法にしたがった。重合方法も既 報16)の方法にしたがい重合速度は重量法でもとめた。重合反応は 均一系で進行する。

液体亜硫酸およびピリジン等の電子スペクトルは，石英製の耐 印光学セルを用いて測定したが，七ル幅は $2 \mathrm{~mm}$ ，スペーサー $1.97 \mathrm{~mm}$ であった。

\section{3 結果}

\section{1 液体亜硫酸とピリジンの電荷移動型錯合体}

n-ヘキサン中の液体亜硫酸とピリジンの電子スペクトルを図 1に示したが，錯合体の吸収は 263 と $287 \mathrm{~m} \mu$ に認められる。

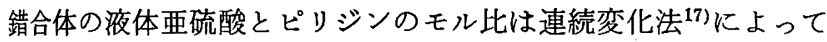
もとめたが錯合体の吸光度の最大值はピリジン溶液の約 33 vol\% のところにあって，錯合体組成は，液体亜硫酸とピリジンの比が 2:1 であることが分る（図 2 ）。そしてその錯合体の形としては 次のよ5に考光るのが合理的と思われる(図 3 )。すなわち，窒素 の不対電子対にもとづく遷移の吸収は $263 \mathrm{~m} \mu$ に，ピリジン環の $\pi$ 電子にもとづく吸収は $287 \mathrm{~m} \mu$ にそれぞれ対応させて考えるこ とができると思われる。それ故平衡定数， $K\left(l^{2} / \mathrm{mol}^{2}\right)$ は（2） 式で表わされる。

$$
\begin{aligned}
& \mathrm{Py}+2 \mathrm{SO}_{2} \stackrel{K}{\rightleftarrows} \text { Complex }(\equiv \mathrm{C}) \\
& K=\frac{[\mathrm{C}]}{\left(\left[\mathrm{SO}_{2}\right]_{0}-2[\mathrm{C}]\right)^{2}\left([\mathrm{Py}]_{0}-[\mathrm{C}]\right)}
\end{aligned}
$$

ここで，Py とCはそれぞれピリジンと錯合体を表わし，錯合 体の濃度，[C] は次式で执きかえることができる。

$$
\text { [C], }(\mathrm{mol} / \mathrm{l})=0 . \mathrm{D} \text {. due to complex } / \varepsilon_{\mathrm{c} d}
$$

ここで， $\varepsilon_{\mathrm{c}}$ は錯合体の分子吸光係数を，O.D. は吸光度を， $d$ は光学セルの光の通過する幅 $(\mathrm{cm})$ をそれぞれ表わす。平衡定数 が比較的小さい場合には錯合体濃度の二乗以上を含む項を無視す ることができるので，次のような関係式が容易にえられる。

$$
\frac{[\mathrm{Py}]_{0}\left[\mathrm{SO}_{2}\right]_{0}^{2} d}{\text { O.D. }}=\frac{1}{\varepsilon_{\mathrm{c}} K}+\frac{1}{\varepsilon_{\mathrm{c}}}\left\{4\left[\mathrm{SO}_{2}\right]_{0}[\mathrm{Py}]_{0}+\left[\mathrm{SO}_{2}\right]_{0}^{2}\right\}
$$

したがって, $[\mathrm{Py}]_{0}\left[\mathrm{SO}_{2}\right]_{0}^{2} / d \mathrm{O} . \mathrm{D}$. と $4\left[\mathrm{SO}_{2}\right]_{0}[\mathrm{Py}]_{0}+\left[\mathrm{SO}_{2}\right]_{0}^{2}$ をプロットすれば勾配より $\varepsilon_{\mathrm{c}}$ ，切片よりKをむとめることがで きる。この関係は図 4 に示され（4）式は満足され，20 ける平衡定数として $0.028\left(l^{2} / \mathrm{mol}^{2}\right)$ がえられた。

17) P. Job, Compt. Rend., 180, 928 (1925) ; Ann. Chim. Phys., [10], 9, 113 (1928).

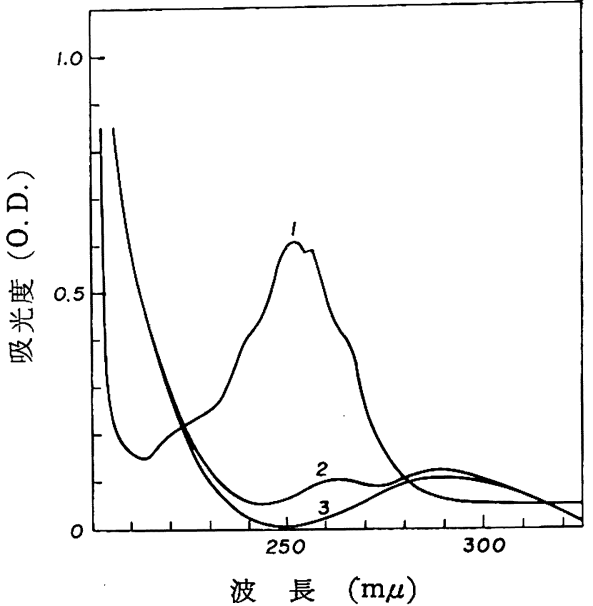

図 1 ピリジン $(\mathrm{Py})$, 液体要硫酸, ピリジン一液体亜硫酸の電子 スペクトル $\left(n\right.$ 一キキン中 $20^{\circ} \mathrm{C}$ ，七ル幅は $\left.3.3 \times 10^{-2} \mathrm{~cm}\right)$

1: $[\mathrm{Py}]=1.06 \times 10^{-2} \mathrm{~mol} / l$ (ref. は $n$-ヘキサン)

2: $\left[\mathrm{SO}_{2}\right]=1.08 \times 10^{-2},[\mathrm{Py}]=1.06 \times 10^{-2} \mathrm{~mol} / l\left(\right.$ ref. $\left.[\mathrm{Py}]=1.06 \times 10^{-2} \mathrm{~mol} / \mathrm{l}\right)$ $3:\left[\mathrm{SO}_{2}\right]=1.19 \times 10^{-2} \mathrm{~mol} / \mathrm{l}$

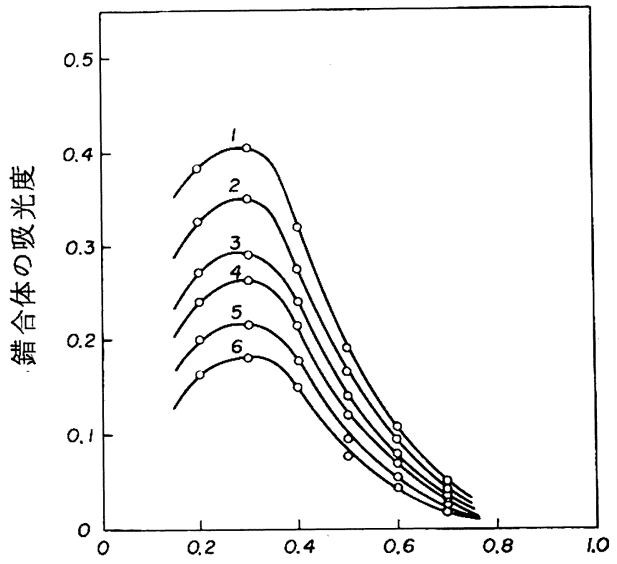

$[\mathrm{Py}] /\left([\mathrm{Py}]+\left[\right.\right.$ liq $\left.\left.\mathrm{SO}_{2}\right]\right)$

図 2 連続変化法による液体垔硫酸とピリシンの錯合体 の電子スペクトル $\left([\mathrm{Py}]+\left[\mathrm{liq} \mathrm{SO}_{2}\right]=3.0 \mathrm{~mol} / l\right.$, メタノール溶液, $20^{\circ} \mathrm{C}$ )

$1: 3275 \AA$ А $2: 3300 \AA, 3: 3325 \AA, 4: 3350 \AA, 5: 3375 \AA$ A, $6: 3400 \AA$

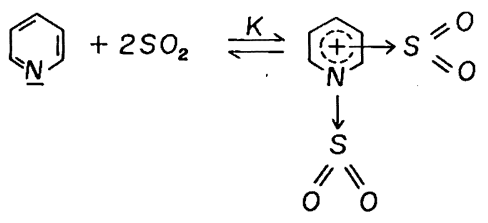

図 3 液体亜硫酸とピリシンンの電荷移動型錯合体

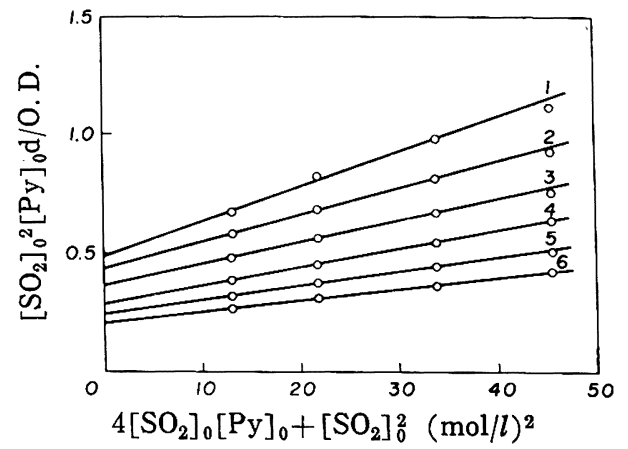

図 4 (4) 式のプロット

$1: 3375 \AA, 2: 3350 \AA, 3: 3325 \AA$, $4: 3300 \AA, 5: 3275 \AA, 6: 3250 \AA$ (セル幅 $(d) 3.3 \times 10^{-2} \mathrm{~cm}$ ) 


\section{$3 \cdot 2$ 液体亜硫酸とピリジンの電荷移動型錯合体-四塩化炭素系} によって開始されたメタクリル酸メチルの重合におよほ す有機ハロゲン化合物の影響

メタクリル酸メチルの初濃度 $\left([\mathrm{MMA}]_{0}\right)$ を $2.82 \mathrm{~mol} / l,[\mathrm{Py}]_{0}$ を $3.71 \mathrm{~mol} / \mathrm{l}$, 有機ハロゲン化合物のうちで常温で液体のものは $10 \mathrm{vol} \%$ ，固体のものは $3.0 \mathrm{~g}$ と一定に保ち $50^{\circ} \mathrm{C}$ で 180 分間 加熱した。重合系の希釈剂としてはトルェンを選び，全重合速度 なども求めたが，トルエンは誘電率が低くモノマー，ポリマー, それ錯合体もよく溶解し液体亜硫酸との相互作用もハロゲン化 合物をのぞけばその次に小さく2)，重合反応に無関係な溶媒と考 えることができる。予備的な重合結果を表 1 亿示した。実験番号 の $41,141 ， 16$ より錯合体，すなわち液体亜硫酸とピリジン， および四塩化炭素のいずれがなくとも重合は進行しないことが分 る。

表 1 種々の有機ハロゲン化合物の存在下に液体亜硫 酸とピリシンの電荷移動型錯合体でメタクリル酸 メチルを重合させてえた結果 $\left(50^{\circ} \mathrm{C}\right)$

\begin{tabular}{|c|c|c|c|c|c|}
\hline \multirow{2}{*}{$\begin{array}{l}\text { 実験 } \\
\text { 番号 }\end{array}$} & \multirow{2}{*}{$\begin{array}{l}\text { ピソシシン } \\
\text { (電子借与体) } \\
(\mathrm{mol} / \mathrm{l})\end{array}$} & \multirow{2}{*}{ 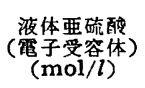 } & \multicolumn{2}{|c|}{ 有機ハロゲン化合物 } & \multirow{2}{*}{ 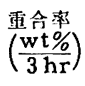 } \\
\hline & & & 化合物名 & $(\mathrm{mol} / \mathrm{l})$ & \\
\hline 41 & 3.71 & 3.04 & - & - & Nil \\
\hline 141 & - & 3.04 & 四塩化炭秦 & 1.03 & $" \prime$ \\
\hline 16 & 3.71 & - & " & 1.03 & " \\
\hline 1 & $"$ & 3.04 & " & 1.03 & 17.0 \\
\hline 519 & " & " & クロロホルム & 3. 21 & $\mathrm{Nil}$ \\
\hline 520 & " & " & ジクロルメタン & 1.55 & " \\
\hline 523 & " & " & 四臭化炭泰 & 0.57 & " \\
\hline 522 & $"$ & " & ブロモホルム & 1.14 & 7.3 \\
\hline 521 & " & " & ジクロル酶酸 & 1.21 & 5.1 \\
\hline
\end{tabular}

次に，この重合反応の連鎖担体がラジカルであるかイオンであ るかを知るために, 種々のタイプの禁止剂を加え, その効果を検 討した。

ピリジンといら塩基が存在する重合系ではあるが，カチオン重 合の可能性をチェックするためにジメチルホルムアミド (DMF) を添加した。著者ら $\left.{ }^{14}\right)$ は以前液体亜硫酸中のスチレンおよびその 誘導体のルイス酸によるカチォン重合が DMF で完全に禁止され ることを見い出している。表 2 に示したように DMF の添加は重 合反応を非常に加速したが，この効果については次報で報告する。 $\mathrm{DPPH}$ を $5 \times 10^{-5} \mathrm{~mol} / l$ と非常に薄い濃度で加えたときには, 液体亜硫酸ーピリジンー四塩化炭素系の場合には瞬間的に消色する のが認められた。後で述べる動力学の結果と合せ, 本重合系はラ ジカル機構で進行していると判定できる。

表 2 液体亜硫酸とピリシンの電荷移動型錹合体一四塩化炭 素系で開始されたメタクリル酸メチルの重合に扰よぼす 禁止剤の効果（重合条件は表 1 の実験番号 1 と同じ）

\begin{tabular}{|c|c|c|c|}
\hline $\begin{array}{l}\text { 実験 } \\
\text { 皇 }\end{array}$ & 禁止郕 & 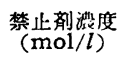 & $\begin{array}{c}\text { 重弇率 } \\
(\mathrm{wt} \% / 3 \mathrm{hr})\end{array}$ \\
\hline 1 & - & - & 17.0 \\
\hline 3 & ヒドロキノン & 0.10 & 17.1 \\
\hline 5 & $\mathrm{DPPH}^{\mathrm{a})}$ & 0.08 & 4.3 \\
\hline 7 & $\mathrm{DMF} b$ & 1.96 & 57.8 \\
\hline
\end{tabular}

a) ジフェニルピクリルヒドラジル b) ジメチルホルムアミド

\section{$3 \cdot 3$ メタクリル酸メチルの重合速度におよぼす錯合体濃度の} 影響

全重合反応速度 $R_{\mathrm{p}}(\mathrm{mol} / l \cdot \mathrm{sec})$ と（2）式をつかってえた錯 合体濃度の平方根の関係を図 5 に示したが， $R_{\mathrm{p}}$ は [C] の平方 根に比例していることがわかる。なお， $50^{\circ} \mathrm{C}$ における [C] の 値は（1）式の $\Delta H=-1.4 \pm 0.2^{7)} \mathrm{kcal} / \mathrm{mol}$ を用い計算した。

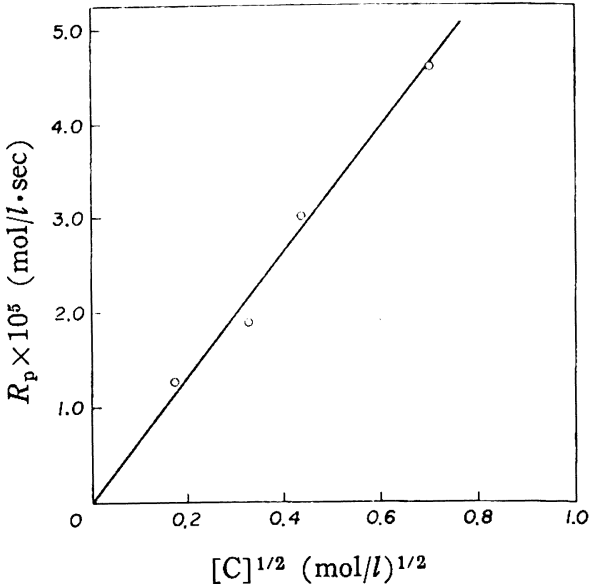

図 5 全重合反応速度 $\left(R_{\mathrm{p}}\right)$ と錯合体濃度 $([\mathrm{C}])$ の $1 / 2$ 乗のプロット

$[\mathrm{M}]=3.29 \mathrm{~mol} / \mathrm{l} \quad\left[\mathrm{CCl}_{4}\right]=0.52 \mathrm{~mol} / l$

$\left(50^{\circ} \mathrm{C}\right)$

\section{4 $\boldsymbol{R}_{\mathrm{p}}$ におよばす $[\mathrm{MMA}]_{0}$ の影響}

図6に示したように $R_{\mathrm{p}}$ は $[\mathrm{MMA}]_{0}$ の 1.5 乗に比例してい ることになる。したがって $R_{\mathrm{p}}$ は，

$$
R_{\mathrm{p}} \propto[\mathrm{C}]^{0.5}[\mathrm{M}]_{0}{ }^{1.6}
$$

となる。ここで $[\mathrm{M}]_{0}$ はメタクリル酸メチルモノマーの初濃度で める。

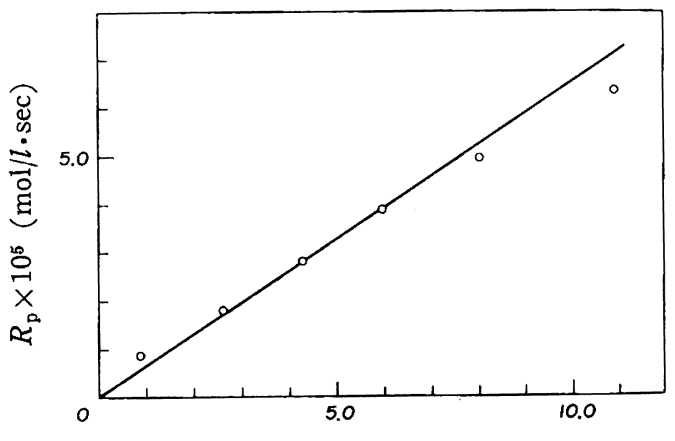

$[\mathrm{M}]^{1.5}(\mathrm{~mol} / \mathrm{l})^{1.5}$

図 6 全重合反応速度 $\left(R_{\mathrm{p}}\right)$ とモノマー濃度の 1.5 乗とのプロット

$\left[\mathrm{CCl}_{4}\right]_{0}=0.52 \mathrm{~mol} / \mathrm{l}$ 錯合休沄度は $0.55 \mathrm{~mol} / \mathrm{l} \quad\left(50^{\circ} \mathrm{C}\right)$

$3.5 \boldsymbol{R}_{\mathrm{p}}$ におよぼす四塩 化炭素濃度の影響

図 7 にその関係は示した が, 四塩化炭素濃度が 約 $0.15 \mathrm{~mol} / l$ までは四塩化炭 素濃度の増加にともなって $R_{\mathrm{p}}$ は急激に増加するが, その後は $R_{\mathrm{p}}$ は四塩化炭素 濃度に，無関係となってい る。

$3 \cdot 6$ 全反応の活性化工 ネルギー

全反応の活性化エネルギ 一, E ( kcal $/ \mathrm{mol})$ は図 8 Arrhenius のプロットより 8.2 と求められたが, 後で のベるように $k_{\mathrm{p}} / k_{\mathrm{t}}{ }^{1 / 2}$ の值

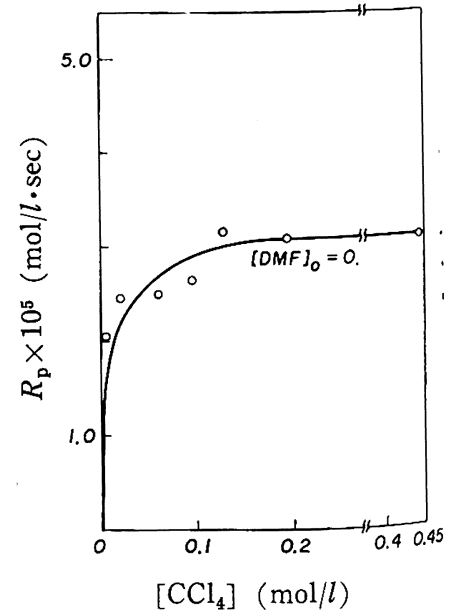

図 7 全重合反応速度 $\left(R_{\mathrm{p}}\right)$ と 四塩化炭装濃度との関係 $[\mathrm{MMA}]=2.82 \mathrm{~mol} / l$, 鍇合体洪度 ([C]) は $5.5 \times 10^{-1} \mathrm{~mol} / l,(50 \mathrm{C})$ 


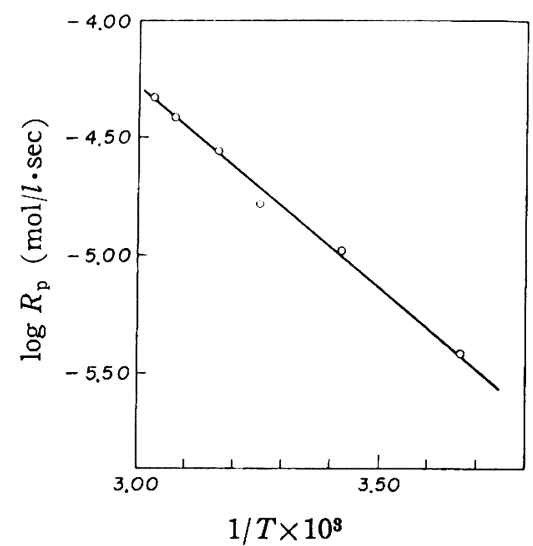

因 8 全重合反応速度の Arrhenius のプロット

とから，開始反応の活性化エネルギーの計算に用いられた。な お，温度を変えたことにともなう［C] の補正は行なっていない。

\section{7 平均分子量}

粘度法により数平均の重合度 $\bar{P}_{\mathrm{n}}$ をるとめ, 次式の 関係で,

$$
-\bar{P}_{\mathrm{n}} \frac{\mathrm{d}[\mathrm{M}]}{\mathrm{d} t}=\frac{k_{\mathrm{p}}{ }^{2}}{k_{\mathrm{t}}}[\mathrm{M}]^{2}
$$

$k_{\mathrm{p}} / k_{\mathrm{t}}{ }^{1 / 2}$ の值を計算した。ここで $k_{\mathrm{p}}$ と $k_{\mathrm{t}}$ はおのおの生長と停 止反応の速度定数 $(l / \mathrm{mol} \cdot \mathrm{sec})$ である。

表 3 種々の重合条件から求めた $k_{\mathrm{p}} / k_{\mathrm{t}}{ }^{1 / 2}\left(50^{\circ} \mathrm{C}\right)$

\begin{tabular}{|c|c|c|c|c|c|}
\hline $\begin{array}{l}{[\mathrm{MMA}]_{0}} \\
(\mathrm{~mol} / \mathrm{l})\end{array}$ & $\begin{array}{c}{[\mathrm{C}]} \\
(\mathrm{mol} / \mathrm{l})\end{array}$ & $\begin{array}{l}{\left[\mathrm{CCl}_{4}\right]_{0}} \\
(\mathrm{~mol} / \mathrm{l})\end{array}$ & $10^{-3} \bar{P}_{\mathrm{n}}$ & $\begin{array}{l}-10^{5} \frac{\mathrm{d}[\mathrm{M}]}{\mathrm{d} t} \\
(\mathrm{~mol} / / \cdot \mathrm{sec})\end{array}$ & $\begin{array}{c}k_{\mathrm{p}} / k_{\mathrm{t}}^{1 / 2} \\
\left(l^{1 / 2} / \mathrm{mol}^{1 / 2} \cdot \sec ^{1 / 2}\right)\end{array}$ \\
\hline 0.94 & 0.553 & 0.52 & 3.72 & 0.783 & 0.182 \\
\hline 4.00 & 0.553 & 0.52 & 5.78 & 4. 883 & 0.134 \\
\hline 3.29 & 0.031 & 0.52 & 13.80 & 1.285 & 0.128 \\
\hline 3.29 & 0.117 & 0.52 & 7.71 & 1.894 & 0.116 \\
\hline 3. 29 & 0.224 & 0.52 & 9. 26 & 3.028 & 0.161 \\
\hline 3. 29 & 0725 & 0.52 & 3. 91 & 4. 602 & 0.129 \\
\hline 2.82 & 0553 & 013 & 9.59 & 3220 & 0.197 \\
\hline 2.82 & 0.553 & 0.19 & 9. 39 & 3. 213 & 0.195 \\
\hline \multirow[t]{2}{*}{2.82} & 0.553 & 0.32 & 9. 56 & 3. 213 & 0.199 \\
\hline & & & & & 平均 0.160 \\
\hline
\end{tabular}

ここでえた $k_{\mathrm{p}} / k_{\mathrm{t}} \mathrm{t}^{1 / 2}$ の值は文献值, $0.125\left(l^{1 / 2} / \mathrm{mol}^{1 / 2} \cdot \mathrm{sec}^{1 / 2}\right)$ $\left(50^{\circ} \mathrm{C}\right)^{18)}$ と比較しうるものであり, ラジカル機構で進行してい ることを支持するデータの一つである。

\section{8 開始反応の活性化エネルギー $\left(\boldsymbol{E}_{\mathbf{i}}\right)$}

重合温度 $20 \sim 60^{\circ} \mathrm{C}$ でえたポリマーの $k_{\mathrm{p}} / k_{\mathrm{t}}{ }^{1 / 2}$ を同様にしても とめ，これを Arrhenius の関係でプロットした（図 9 )。さきの 全活性化エネルギーEと図 9 からえられる生長反応の活性化エネ

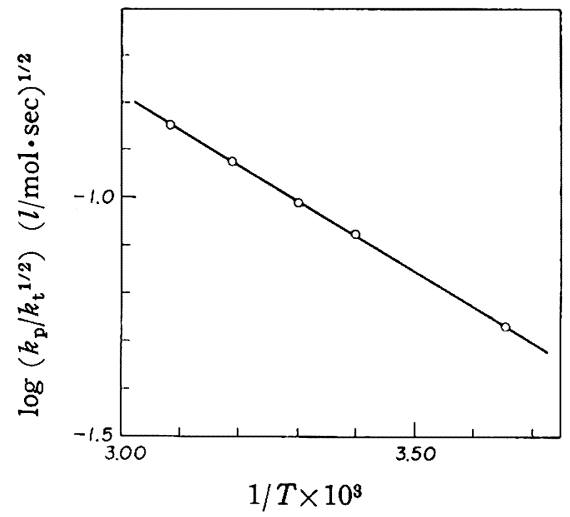

図 $9 k_{\mathrm{p}} / k_{\mathrm{t}}{ }^{1 / 2}$ の Arrhenius のプロット

18) J.Bevington, Trans. Faraday Soc., 53, 997 (1957).
ルギーと，停止反応の活性化エネルギーの差 $\left(E_{\mathrm{p}}-1 / 2 E_{\mathrm{t}}=3.4\right.$ $\mathrm{kcal} / \mathrm{mol})$ より，閉始反応の活性化エネルギーとして $E_{\mathrm{i}}=9.7$ ( $\mathrm{kcal} / \mathrm{mol}$ )をえた。

\section{4 考察}

$N$-ビニルカルバゾールはクロラニル，テトラニトロメタン， 無水マレイン酸のような比校的強い留子受容体 ${ }^{19,20)}$ に限らず，広 い範囲の電子親和力をもった有機の電子受容体によって容易に重 合することが報告9 11) されている。四塩化炭素は弱い電子受容体

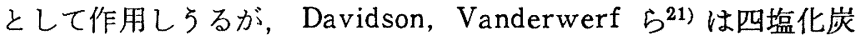
素とピリジンおよびその誘導体との鍇合体の存在について報告し ている。また, Bamford ら 22 26) は金属カルボニルによって開始 されたメタクリル酸メチルのラジカル重合に拈よぼす四塩化炭素 の効果について研究を行なっている。

本重合系に打いては，ピリジンは液体亚硫酸と四塩化炭素の両 方に対して，電子供与体として作用していることになるが，図 1 と図 2 に示したように，液体亜硫酸とピリジンの錯合体について は検知されたが，四塩化炭素とピリジンのそれについては電子ス ペクトルからは検知できなかった。そして，表 1 の実験番号 16 からもわかるとおり，四塩化炭素とピリジンそれにモノマーの系 からは重合はまったく開始されていない。したがってメタクリル 酸メチルの重合に活性な錯合体は，液体亜硫酸とピリジンの錯合 体だけであると考えられる。液体亚硫酸とピリジンの錯合体につ いては Hoffman 5 ${ }^{27)}$ は, 混合溶液の融点と溶液組成の関係から 1:1 の錯合体が生成していると報告している。 $1: 1$ 組成の錯合 体については Hildebrand の式 ${ }^{28)}$ を一般に満足するはずであるが 著者らの実験ではこの関係は浾足されなかった。そして Hoffman らのえた cryoscopic なデータは錯合体の結晶状態に関与したも ル比を与えるのであって，溶液状態に拈ける錯合体組成と同じで ある必要はなく, 著者らは $2: 1$ 錯合体としてその濃度を計算し た。

液体要硫酸とピリジンの 錯合体-四塩化炭素系による重合は, ラジカル中間体を考劣るのが最も合理的であると思われる。すな わち, DPPH によって重合が抑制されること, DMF という塩基 を加えても抑制されないこと，アニオン重合は液体亜硫酸の共存 下では起こりえないこと， $k_{\mathrm{p}} / k_{\mathrm{t}}{ }^{1 / 2}$ の值が典型的なラジカル重合 からえられている值に近いこと，などの結果がえられるからであ

19) H. Scott, G. A. Miller, M. M. Labes, Tetrahedron Letters, No. 17, 1073 (1963).

20) L. P. Ellinger, Chem. Ind., 1963, 1982.

21) A. W. Davidson, C. A. Vanderwerf, L. G. Boatright, J. Am. Chem. Soc., 69, 3045 (1947).

22) C. H. Bamford, C. A. Finch, Trans. Faraday Soc., 59, 118 (1963).

23) C. H. Bamford, C. A. Finch, Proc. Roy. Soc., A 268, 553 (1962).

24) C. H. Bamford, C.A.Finch, Trans. Faraday Soc., 59 , 540 (1963).

25) C. H. Bamford, G.C. Eastmond, W. R. Maltman, ibid., 61, 267 (1965).

26) C. H. Bamford, G. C. Eastmond, J.A. Rippon, ibid., 59, 2548 (1963).

27) K. R. Hoffman, C. A. Vanderwerf, ibid., 68, 997(1946).

28) H. A. Benesi, J.H. Hildebrand, J. Am. Chem. Soc., 71, 2703 (1949). 
る。

重合は錯合体，もしくは四塩化炭素が存在しないと開始されな い。そして速度と四塩化炭素の関係はその浱度が低いときに非常 に敏感であるが濃度が大きくなるにつれて無関係になる。一方， 速度は錯合体濃度の平方根とモ>マ一濃度の 1.5 乗に比例してい る。これらの結果は次のような開始のメカニズムによって説明す ることができる。

$$
\begin{gathered}
\left.\mathrm{C}+\mathrm{M} \underset{k_{2}}{\stackrel{k_{1}}{\rightleftharpoons}} \text { ( I }\right) \\
\left.(\mathrm{I})+\mathrm{CCl}_{4} \stackrel{k_{3}}{\longrightarrow} \mathrm{Cl}_{3} \mathrm{CM} \cdot \stackrel{\ominus}{\mathrm{Cl}}\left(\rightarrow \mathrm{SO}_{2}\right)+\text { (II }\right)
\end{gathered}
$$

錯合体とモノマーからなる会合体（I）の生成は可逆的である と仮定するが，実験的には平衡の存在は確認していない。しかし モノマー濃度の 1.5 乘に比例する実験結果は開始種とモノマーの 平衡によって説明されてきている29)。（I）は四塩化炭素と反応 してモノマーラジカルと（II）(これは多分ラジカルカチオンで あると思われるが）を与える。クロルアニオンは液体亜硫酸の溶 媒和を受けて安定化しているであろう。（I）の濃度について定 常状態を仮定すると開始反応の速度 $v_{\mathrm{i}}(\mathrm{mol} / l \cdot \mathrm{sec})$ は，次式の上 らに与えられる。

$$
v_{\mathrm{i}}=\frac{k_{1} k_{3}[\mathrm{C}][\mathrm{M}]\left[\mathrm{CCl}_{4}\right]}{k_{2}+k_{3}\left[\mathrm{CCl}_{4}\right]}
$$

全重合反応速度 $\left(R_{\mathrm{p}}\right)$ は生長反応速度 $v_{\mathrm{p}}$ によって近似できる

$$
R_{\mathrm{p}}=v_{\mathrm{p}}=-\frac{\mathrm{d}[\mathrm{M}]}{\mathrm{d} t}=k_{\mathrm{p}}[\mathrm{M} \cdot][\mathrm{M}]
$$

から，系のラジカル濃度の定常状態と二分子停止反応を仮定する

と（11）式に導かれる。

$$
\begin{aligned}
R_{\mathrm{p}} & =k_{\mathrm{p}}[\mathrm{M}]\left(\frac{v_{\mathrm{i}}}{k_{\mathrm{t}}}\right)^{1 / 2} \\
& =\frac{k_{\mathrm{p}}}{k_{\mathrm{t}}{ }^{1 / 2}}[\mathrm{M}]\left(\frac{k_{1} k_{3}[\mathrm{C}][\mathrm{M}]\left[\mathrm{CCl}_{4}\right]}{k_{2}+k_{3}\left[\mathrm{CCl}_{4}\right]}\right)^{1 / 2}
\end{aligned}
$$

この速度式は実験結果とよく一致している。すなわち，錯合体 濃度の平方根とモノマー濃度の 1.5 乗に, そして四塩化炭素濃度 との関係については図 7 の関係を満足している。四塩化炭素濃度 が低いときには，速度はその濃度とともに增加し，濃度が大きく なって $k_{3}\left[\mathrm{CCl}_{4}\right] \gg k_{2}$ になったときには速度に無関係となる。こ

29) G. Schulz, F. Blaschke, Z. Phys, Chem., 39 B, 246 (1938) ; ibid., 51 B, 75 (1942).
の全速度式の誘導に当っては，しかしながら，（1）式を予俏平 衡と考えており，この仮定は実験結果との完全な一致から妥当な ものと思われる。錯合体の濃度はモノマーを含んだ重合系から求 めることはできないので，別個の実験（3.1）で求めたものを速 度定数の計算に使用した。

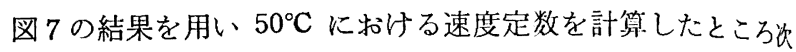
の值を党た。

$$
\begin{aligned}
& k_{1}=4.61 \times 10^{-9}(l / \mathrm{mol} \cdot \mathrm{sec}) \\
& k_{2} / k_{3}=2.24 \times 10^{-2}(\mathrm{~mol} / \mathrm{l})
\end{aligned}
$$

全速度式はしたがって,

$$
R_{\mathrm{p}}=3.35 \times 10^{-5}\left(\frac{\left[\mathrm{CCl}_{4}\right]}{2.24 \times 10^{-2} \times\left[\mathrm{CCl}_{4}\right]}\right)^{1 / 2}
$$

もしくは,

$$
R_{\mathrm{p}}=1.09 \times 10^{-5}\left(\frac{[\mathrm{M}]^{3}[\mathrm{C}]\left[\mathrm{CCl}_{4}\right]}{2.24 \times 10^{-2}+\left[\mathrm{CCl}_{4}\right]}\right)^{1 / 2}
$$

そして開始反応の速度は，

$$
v_{\mathrm{i}}=5.53 \times 10^{-9}\left(\frac{\left[\mathrm{CCl}_{4}\right]}{2.24 \times 10^{-2}+\left[\mathrm{CCl}_{4}\right]}\right)
$$

がえられた。因 7 の実線は（12）もしくは（13）式を用いて画か れたものである。

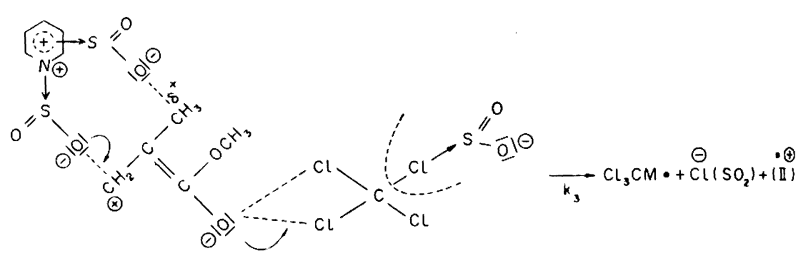

associated complex

図 10 動力学の結果より推論した開始反応機䔩

図 10 には会合体（I）に上る四塩化炭素の還元の機構を図的 に表わしたが，むちろんこれは単なる想像にすぎないが動力学の 結果にしたがって画かれている。塩素アニオンは液体亜硫酸の溶 媒和を受けて安定化していると考劣るが，これがこの反応の起こ り易さを助長していると考える。この機構は酸化還元反応であり これに相当して開始の活性化エネルギーも，一般のラジカル關始 剤を用いたときのそれ（約 $30 \mathrm{kcal} / \mathrm{mol}$ ) にくらべて低くなって いる。 